\title{
The knowledge spillover theory of entrepreneurship
}

\author{
Zoltan J. Acs · Pontus Braunerhjelm • \\ David B. Audretsch · Bo Carlsson
}

Accepted: 5 November 2008/Published online: 13 December 2008

(C) The Author(s) 2008. This article is published with open access at Springerlink.com

\begin{abstract}
Contemporary theories of entrepreneurship generally focus on the recognition of opportunities and the decision to exploit them. Although the entrepreneurship literature treats opportunities as exogenous, the prevailing theory of economic growth suggests they are endogenous. This paper advances the microeconomic foundations of endogenous growth theory by developing a knowledge spillover theory of entrepreneurship. Knowledge created endogenously results in knowledge spillovers, which allow entrepreneurs to identify and exploit opportunities.
\end{abstract}

\section{Z. J. Acs $(\square)$}

School of Public Policy, George Mason University,

Fairfax, VA, USA

e-mail: zacs@gmu.edu

\section{P. Braunerhjelm}

Department of Transport and Economics, The Royal Institute of Technology, Stockholm, Sweden

e-mail: pontusb@infra.kts.se

D. B. Audretsch

School of Environmental and Public Affairs, Indiana

University, Bloomington, IL, USA

e-mail: daudrets@indiana.edu

\section{B. Carlsson}

Weatherhead School of Management, Department of Economics, Case Western Reserve University, Cleveland, $\mathrm{OH}, \mathrm{USA}$

e-mail: Bo.Carlsson@case.edu
Keywords Opportunity - Knowledge ·

Entrepreneurship · Endogenous growth - Start-ups · New product innovation

JEL Classifications $\quad \mathrm{J} 24 \cdot \mathrm{L} 26 \cdot \mathrm{M} 13 \cdot \mathrm{O} 3$
Any course of action must expose the chooser to numberless different sequels, rival hypotheses, some desired and some counter-desired...The entrepreneur is a maker of history, but his guide in making it is his judgment of possibilities and not a calculation of certainties.

G.L.S. Shackle (1982, vii)

\section{Introduction}

Where do entrepreneurial opportunities come from? Endogenous growth models suggest R\&D activities are "purposeful investment in new knowledge" undertaken by profit-maximizing firms, where knowledge is an input in the process of generating endogenous growth (Romer 1990; Segerstrom et al. 1990; Aghion and Howitt 1992). ${ }^{1}$ The set of technological opportunity is endogenously created by

\footnotetext{
${ }^{1}$ Griliches (1979) formalized the knowledge production function. In this model, firms are also exogenous and pursue new economic knowledge as an input into future innovative activity.
} 
investments in new knowledge. Technological change is central in explaining economic growth: The rate of per capita GDP growth equals the rate of technological change on the steady state growth path. This explanation assumes that efficiency of knowledge production is enhanced by the historically developed stock of scientific-technological knowledge. ${ }^{2}$

In addition to facilitating technological change, knowledge also generates opportunities for third-party firms (Jaffe et al. 1993; Thompson and Fox-Kean 2005), which are often entrepreneurial start-ups (Shane 2001). This occurs through intra-temporal knowledge spillovers. Therefore, entrepreneurial activity involves both arbitrage of opportunities (Kirzner 1973) and exploitation of new opportunities created, but not appropriated by incumbent firms (Schumpeter 1934).

Endogenous growth models are based on strong assumptions for the technical ease and analysis. However, these advantages impose drawbacks of deviations from real-world behavior.

The endogenous growth framework offers no insight into what role, if any, entrepreneurial activity plays in the intra-temporal spillover of tacit knowledge. While the new growth theory enhances our understanding of the growth process, the essence of the Schumpeterian (1934) entrepreneur is missed. As a result, endogenous growth models fail to incorporate a crucial element in the process of economic growth: Transmission of knowledge spillovers through entrepreneurship (Audretsch 1995). This implies that knowledge by itself is only a necessary condition for the exercise of successful enterprise in a growth model. An interesting approach recently focuses on the allocation of societal resources spent on R\&D and entrepreneurship. Michelacci (2003) concludes that low rates of return to R\&D may be due to lack of entrepreneurial skills. Hence, the ability to transform new knowledge into economic opportunities involves a set of skills, aptitudes, insights and circumstances that is neither uniformly nor widely distributed in the population.

This paper develops a knowledge spillover theory of entrepreneurship to improve the microeconomic foundations of endogenous growth

\footnotetext{
${ }^{2}$ This is not a fixed stock of knowledge. For example, change introduced by an entrepreneur can make part of the existing stock of knowledge obsolete.
}

models, in which the creation of knowledge expands technological opportunity. The theory shifts the unit of analysis from exogenously assumed firms to individual agents with new knowledge endowments. Agents with new economic knowledge endogenously pursue the exploitation of such knowledge, implying that the existing stock of knowledge yields spillovers. This further suggests a strong relationship between such knowledge spillovers and entrepreneurial activity. The theory provides an explanation for the role of the individual and the firm in an economy. According to Romer (1996, 204), such an approach “...removes the dead end in neoclassical theory and links microeconomic observations on routines, machine designs, and the like with macroeconomic discussions of technology."

The model is one where new product innovations can come both from either incumbent firms or startups (Acs and Audretsch 1988). ${ }^{3}$ We can think of incumbent firms as reliant on incremental innovation from the flow of knowledge, such as product improvements. Start-ups with access to entrepreneurial talent and intra-temporal spillovers from the stock of knowledge are more likely to engage in radical innovation leading to new industries or replacing existing products. ${ }^{4}$ According to Baumol (2004, 9): "...the revolutionary breakthroughs continue to come predominantly from small entrepreneurial enterprises, with large industry providing streams of incremental improvements that also add up to major contributions." Entry by start-ups has played a major role in radical innovations, such as software, semiconductors, biotechnology (Zucker et al. 1998) and the information and communications technologies (Jorgenson 2001). Start-ups are especially important at early stages of the life cycle, when technology is still fluid. Therefore, this paper makes the strong assumption that radical innovation comes from new firm start-ups.

\footnotetext{
3 Acs and Audretsch (1988) find that, ceteris paribus, the greater extent to which an industry comprises large firms, the greater will be innovative activity, but increased innovative activity will tend to come from small firms rather than large firms.

4 A large amount of literature exists that shows how entrepreneurial start-ups use networks to access the stock of knowledge.
} 
The main predictions of the model are:

1. An increase in the stock of knowledge has a positive effect on the level of entrepreneurship.

2. The more efficiently incumbents exploit knowledge flows, the smaller the effect of new knowledge on entrepreneurship.

3. Entrepreneurial activities decrease under greater regulation, administrative burden and market intervention by government.

Thus, entrepreneurship contributes to economic growth by acting as a conduit ${ }^{5}$ through which knowledge created by incumbent firms spills over to agents who endogenously create new firms. Opportunities are created when incumbent firms invest in, but do not commercialize, new knowledge. In this theory, entrepreneurship is a response to these opportunities. We suggest that, ceteris paribus, entrepreneurial activity will be greater where investments in new knowledge are relatively high, since start-ups will exploit spillovers from the source of knowledge production (the incumbents). In an environment with relatively low investments in new knowledge, there will be fewer entrepreneurial opportunities based on potential spillovers.

Our theoretical model explains entrepreneurship as a function of the following factors: knowledge stock, R\&D exploitation by incumbents and barriers to entrepreneurship. It considers factors such as risk aversion, legal restrictions, bureaucratic constraints, labor market rigidities, taxes, lack of social acceptance, etc. This explains why economic agents might decide against starting up, even when in possession of knowledge that promises potential profit opportunity. In addition, culture, traditions and institutions are more difficult factors to identify than strictly economic factors, but they also play an important role in entrepreneurship. To capture such country-specific differences, we estimate a reduced form equation with a fixed-effect panel-regression technique.

The paper is organized as follows. The next section examines knowledge spillovers as a source of entrepreneurial opportunity in the endogenous growth framework. We present a formal model in Sect. 2. We test and discuss results in Sects. 3 and 4, using data for the period 1981-2002 for 19 OECD countries. Our

\footnotetext{
$\overline{5}$ It is not, of course, the sole conduit.
}

results show that entrepreneurial activity is strongly influenced by knowledge created but not exploited by incumbent firms. We conclude in the final section.

\section{Knowledge spillovers as source of entrepreneurial opportunity}

In order to enable more realistic applicability, the theory relaxes two central assumptions of the endogenous growth model. The first is that all knowledge is economic knowledge. Arrow (1962) emphasized knowledge as inherently different from traditional factors of production, resulting in a gap between new knowledge $(\mathrm{K})$ and what he termed economic knowledge $\left(\mathrm{K}^{\mathrm{c}}\right){ }^{6}$ The second assumption is the assumed spillover of knowledge. In endogenous growth models, the existence of the factor of knowledge is equated with inter-temporal spillover, which yields endogenous growth. In our model we assume intra-temporal knowledge spillovers from incumbent organizations to start-ups. Moreover, institutions impose a gap between knowledge and economic knowledge $\left(0<\mathrm{K}^{\mathrm{c}} / \mathrm{K}<1\right)$, yielding a lower volume of intratemporal knowledge spillovers (Acs et al. 2004).

Romer (1990) separates economically useful scientific-technological knowledge into two parts: The total set of knowledge consists of non-rival, partially excludable knowledge elements, and the rival, excludable elements of knowledge. Codified knowledge published in books, scientific papers or patent documentations belongs to the first set. This can be only partially excludable: The right of applying a technology for production of a particular good is guaranteed by patenting, but the same technology can be used in other applications as others learn from the patent documentation. Rival, excludable knowledge elements comprise personalized (tacit) knowledge of

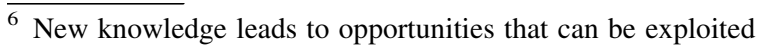
commercially. However, harnessing new ideas for economic growth requires converting new knowledge $(\mathrm{K})$ into "economic knowledge" that holds commercial opportunity. For example, only about half of the invention disclosures in US universities lead to patent applications. Of these applications, about half result in patents issued, of which only $1 / 3$ are actually licensed. Between 10-20\% of licenses actually yield significant income (Carlsson and Fridh 2002, 231). In other words, only 1 or $2 \%$ of the inventions are successful in reaching the market and yielding income.
} 
individuals and groups, including experiences and insights of researchers and business people. This does not go far enough. In the model proposed by Romer (1990), the movement of knowledge from firms producing it to other firms is exogenous. That model explains the effect of knowledge spillovers on technological change without elaborating why or how these spillovers occur. ${ }^{7}$

Why should entrepreneurship play an important role in the intra-temporal spillover of knowledge? New knowledge is characterized by greater uncertainty and asymmetry than other economic goods. Therefore, both the mean expected value of any new idea and its variance will differ across economic agents. If an incumbent firm decides the expected economic value of a new idea is not sufficiently high to warrant its development and commercialization, other economic agents may (or may not) assign a higher expected value to the idea. These agents can operate within or outside of the incumbent firm. This divergence in expected valuation can lead to market entry by economic agents to appropriate new knowledge. The knowledge that induces the decision to start new firms is generated by investments made by an incumbent firm. Thus, the start-up serves as the mechanism through which knowledge spills over from sources that produced it (such as a university or research laboratory in an incumbent firm) to a new organizational form where it is actually commercialized.

One way to reconcile the difference in the role of opportunities in models of entrepreneurship and endogenous growth models is the unit of analysis. Most models of entrepreneurship focus on the individual as the decision-making unit of analysis, whereas the literature on endogenous growth focuses on the firm as the decision-making unit of analysis. In such theories, the firm is exogenous, but its role in generating technological change is endogenous. Therefore, our theory focuses not on exogenously assumed firms, but rather, on the individual agent

\footnotetext{
$\overline{7}$ Knowledge spillovers operate more strongly in some parts of the economy than in others. Particular characteristics tend to be associated with locations with high density of opportunities, such as those hosting high-tech industries. Most innovations occur in high-technology opportunity industries and not lowtechnology opportunity industries (Scherer 1965). The extent to which the results of innovation can be appropriated by incumbent firms also varies among industries.
}

endowed with new economic knowledge. With this new focus, the issue of appropriability remains, but the central question is: How can economic agents with a given endowment of new knowledge best appropriate its returns (Audretsch 1995)?

In the knowledge spillover theory of entrepreneurship, the knowledge production function is reversed. The agent decides to start a new firm based on expected net return from a new product. Accordingly, the inventor would expect compensation for the future value of the potential innovation. In both cases, the employee in the incumbent firm will weigh the alternative of starting a new firm. If expected return from commercialization is sufficiently different for the inventor and for the incumbent decision-maker, and if the cost of starting a new firm is sufficiently low, the employee may choose to leave the incumbent firm to start a new firm. These start-ups typically do not have direct access to a large R\&D laboratory. Rather, they rely on knowledge and experience gained in R\&D laboratories of previous employers, i.e., the incumbents.

This type of labor mobility is likely to be an important source of intra-temporal knowledge spillovers (Pakes and Nitzan 1983). Essentially, R\&D capital is knowledge that can earn a monopoly rent, and this potential rent motivates investment in R\&D. To a large extent, $R \& D$ capital is embodied in $R \& D$ employees $\left(L_{R}\right){ }^{8}$

Hellmann (2007), Lazear (2005), Hvide (2006) and Anton and Yao (1994) proposed models to examine conditions under which agents pursue entrepreneurial activity by starting rival enterprises. Most of this literature addressed incentives where potential externalities could be internalized (Moen 2005), while some have examined circumstances under which employees take advantage of intellectual human capital $\left(L_{E}\right)$ through start-ups (Bhide

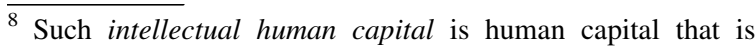
neither publicly available nor perfectly protected. This distinguishes it from ordinary human capital that is widely diffused knowledge and can be acquired at a cost and earns a normal rate of return (Zucker et al. 1998). This distinction between intellectual human capital and ordinary human capital is almost identical to the distinction between rival and non-rival knowledge found in Romer (1990) where rival, excludable knowledge elements are primarily the personalized (tacit) knowledge of individual agents. We assume that the firm owns the intellectual property that results in a start-up.
} 
1994). If an innovation makes the incumbent firm a true monopolist, it will not be profitable for the agent to pursue a start-up, since the sum of rents in a duopolistic market will be less than monopoly rent. This paper does not model the incentive structure under which individual agents become mobile. Instead, it focuses on institutions that prevent the creation of a monopoly in the first place.

\section{Theoretical framework}

To model entry, we partly draw on previous contributions in the endogenous growth literature. In particular, those models introduce a mechanism that fosters innovative entry through investments in R\&D. We will retain that channel of entry, but also demonstrate how knowledge investment by incumbents can spur entry by entrepreneurs that do not engage in R\&D themselves. Since our emphasis is on entry and not growth per se, our aim is not to derive a full-fledged growth model, but rather to focus on the mechanism for entry. ${ }^{9}$

Consider an economy with demand, supply and a financial market. ${ }^{10}$ There are two types of firms: Incumbents undertaking $\mathrm{R} \& \mathrm{D}$ to improve existing products and start-ups exploiting knowledge spillovers and the existing stock of knowledge to innovate new products. Firms that develop an improved or new variety demanded by consumers are rewarded by temporary monopoly profits until new products out compete old ones.

\subsection{Demand side}

Starting with the demand side, consumers maximize standard linear intertemporal utility,

$U=\int_{0}^{\infty} e^{-\rho t} \ln [h(x)] \mathrm{d} t$,

where $\rho t>0$ equals consumer rate of time preference (discount rate) and $h$ is the sub-utility function.

\footnotetext{
$\overline{9}$ See Braunerhjelm et al. (2006) for a growth model.

${ }^{10}$ For details, see Intriligator (1971), Aghion and Howitt (1992) and Dinopoulos (1996).
}

Assume that different varieties of the $\mathrm{x}$-goods are perfect substitutes and that $v^{I}$ refers to the most recent innovated product or variety, with improved quality or novel features. If $v p_{t}<p_{t-1}$, then all consumers will prefer the new product,

$h\left(x_{o}, x_{1}, x_{2} \ldots \ldots\right)=\sum_{I=0}^{\infty} v^{I} x_{I}, \quad v>1$.

The novel products/qualities demanded by consumers may range from research-intensive varieties to products characterized by combining existing knowledge. Hence, high R\&D intensity by itself does not guarantee successful introduction of a new product.

\subsection{Supply side}

On the production side, new products/qualities can be invented either by incumbent firms investing in R\&D or by entrepreneurial start-ups. ${ }^{11}$ Successful entry means a temporary monopoly, where the price of the new product/quality equals the improved property of the product, $v=p_{I}$. The only factor of production is labor, which is allocated among three different activities: R\&D production $\left(L_{R}\right)$, selfemployment through start-ups $\left(L_{E}\right)$ or a residual sector employing R\&D findings and producing final goods $\left(L_{F}\right)$,

$L_{R}+L_{E}+L_{F}=\bar{L}$.

Perfect mobility across sectors assures that wages are equalized. ${ }^{12}$ Initial profit conditions for firms/ products that successfully enter the market are

$\pi=\left(p_{I}-1\right) Y / p_{I}=(v-1) Y / v$

where $p_{I}$ represents the price of the new good, corresponding to the quality improvement $(v)$, and wage is set equal to one. Total consumption expenditure is captured by $\mathbf{Y}$, that is, demand for a new variety. In the long run, free entry implies zero profits. Hence, in the period preceding the introduction of a new product/firm, prices equal wage costs,

\footnotetext{
11 The general production function is $x=\mathrm{AL}^{\gamma}, 0<\gamma \leq 1$.

12 The final good sector is not modeled in order to enhance transparency. It can be viewed as a sector with constant returns to scale, where labor embodied with findings in the R\&D sector at each given time " $t$ " is employed (i.e., labor does not possess skills related to ongoing R\&D).
} 
which are set to one. The first-order condition implies $v=p_{I} \geq 1$.

The introduction of new product innovations occurs either through R\&D outlays by incumbents or through start-ups where existing knowledge is combined in innovative ways. The latter does not require any investment in $\mathrm{R} \& \mathrm{D} .{ }^{13}$ Instead, individuals combine their given entrepreneurial ability $\left(\bar{e}_{j}\right)$ with the overall knowledge stock $(\mathrm{K})$ in an economy to discover commercial opportunities. The societal knowledge stock is a composite of previous knowledge stemming from activities by incumbents and start-ups, i.e., knowledge refers not only to scientific discoveries, but also to novel ways of production and distribution in traditional businesses, changing business models, new marketing strategies, etc. Both types of entry are assumed to occur through a Poisson process.

Hence, the first type of product improvement is related to $R \& D$ expenditures, i.e., it is a flow variable, taking previous scientific knowledge as the departure point. The second type of innovative new product draws instead on the overall stock of knowledge and applies it in a novel way. All innovation implies that some fixed costs are incurred, such as for R\&D or marketing. Innovation is thus modeled consistently with real world behavior.

Starting with incumbents, the aggregate probability of a successful product improvement increases in an economy's R\&D outlays, measured as R\&D

\footnotetext{
$\overline{13}$ To some extent, this parallels the classification of horizontal and vertical innovations (Howitt 1999; Gancia and Zilibotti 2005). The former refers to new products, whereas the latter implies quality improvements in existing products. In the model specification used by Howitt (1999), an increase in R\&D directed towards horizontal innovations may decrease the profit flow accruing to vertical $R \& D$, thereby undermining incentives to undertake vertical innovations. This impairs growth. However, there are considerable differences between the models. The previous literature refers to the discussion on "scale effect" and growth, initiated by Jones (1995). Moreover, in Howitt's model, different production technologies but identical inputs (R\&D staff) are assumed for the two types of innovation, whereas in the present context, identical technologies are assumed, but different factors of production are employed. Finally, the line between an improved quality of an existing variety or a new product that replaces the former product is thin and not necessary for our argument.
}

employees. ${ }^{14}$ As shown above, labor is the only input. The production technology is characterized by decreasing returns to scale $(0<\gamma<1)$. At the firm level, each firm $i$ 's probability $(\mu)$ of successfully launching a new product increases with higher R\&D investments. Thus, innovation by incumbents can be modeled as

$\mu \sum_{i=1}^{n}(\mathrm{R} \& \mathrm{D}) \mathrm{d} t=\mu\left(\sum_{R=1}^{\bar{L}} l_{R}\right) \mathrm{d} t \equiv(1 / \sigma) L_{R}^{\gamma} \mathrm{d} t$

where $\mathrm{d} t$ denotes an infinite increment of time and $(\sigma)$ refers to an efficiency parameter that reflects how smoothly a new discovery is introduced to the market. The second type of innovative new product occurs through start-ups, where the probability of a successful start-up $(\eta)$ is related to the given knowledge stock $\bar{K}$ (at each point in time) times the average entrepreneurial ability $(\hat{e})$ in the economy,

$\eta\left(\sum_{j=1}^{\bar{L}} \overline{e_{j}}\right) \bar{K} \mathrm{~d} t=\eta(\hat{e} \bar{K}) \mathrm{d} t \equiv(1 / \sigma) \bar{K}^{\gamma} \mathrm{d} t$.

At the individual level, the probability of success depends on each individual $j$ 's given endowment of entrepreneurial talent, which is unevenly distributed across the population of $\bar{L}$ individuals in an economy (Lucas 1978). ${ }^{15}$ Also here, decreasing returns to scale $(0<\gamma<1)$ prevail since an increase in entrepreneurial ability will not translate into a proportional increase in start-ups. ${ }^{16}$

The total rate of innovative entry in an economy can be calculated by employing the additive property of Poisson distributions,

$\kappa \mathrm{d} t=\mu \mathrm{d} t+\eta \mathrm{d} t=(1 / \sigma)\left(\bar{K}^{\gamma}+L_{R}^{\gamma}\right) \mathrm{d} t$.

\footnotetext{
${ }^{14}$ The assumed Poisson entry process means that the time frequency with which entry will occur is a random variable whose distribution is exponential with parameter $\mu$, i.e., $\mu$ is the probability per unit of time.

15 We follow Lucas (1978), who assumes that managerial talent is distinct from labor talent. Lazear (2005) assumes that workers and managers have the same two skills in different combinations. Those with more balanced skills are more likely to become entrepreneurs. Those with varied work and educational backgrounds are much more likely to start their own businesses than those who have focused on one role at work or concentrated in one subject at school. The implications for the size distribution of firms are similar in both models.

${ }^{16}$ Moreover, it would not be optimal for all economic activities to be undertaken by entrepreneurs.
} 
Hence, incumbents may now be replaced by rival firms in an R\&D race or by start-ups. ${ }^{17}$

\subsection{The financial market}

To cover investment costs in $\mathrm{R} \& \mathrm{D}$ or other costs, such as marketing, both incumbents and Schumpeterian entrepreneurs must turn to the financial market. ${ }^{18}$ Investors take a risk since start-ups may replace firms, or entrepreneurs may fail. Start-ups are included in investor portfolios prior to entering the market.

Assume that investors can buy shares in all firms in order to minimize risk, implying an average return of $r(t)$. Investors calculate expected returns on their investments over time in the following way. First, a firm's instantaneous profits $\left(\pi=\left(p_{I}-1\right)\left(Y / p_{I}\right)\right)$ and the discounted return $(V)$ - or the value of the firmare linked through the financial market. The (expected) discounted profit is simply the value of the firm at a given time, times the probability it will succeed in inventing $\left(\mu_{j}\right)$ or innovating $\left(\eta_{j}\right)$ new varieties, minus incurred labor costs.

In each period of time $(\mathrm{d} t)$ the shareholder receives a dividend, which is related to profits, and the firm appreciates in value $\dot{V}(t) \mathrm{d} t=(\mathrm{d} V / \mathrm{d} t) \mathrm{d} t$. However, incumbents (whether R\&D-based or the entrepreneurial type) run the risk of being replaced by the introduction of new qualities $(\kappa)$, thereby risking a loss of $V(t)$,

$$
\begin{aligned}
& {[\pi(t) / V(t)] \mathrm{d} t+\dot{V}(t) / V(t)[1-\kappa] \mathrm{d} t} \\
& \quad+[(\dot{V}(t)-V(t)) / V(t)] \kappa \mathrm{d} t=r(t) \mathrm{d} t
\end{aligned}
$$

where $(1-\kappa)$ is the probability that the firm survives and $\kappa$ represents the probability that the firm will be forced out of business. Consequently, investors will incur losses on previous investments. From Eq. 8, as $\mathrm{d} t$ goes to zero,

\footnotetext{
17 The same factors that are identified by the theory developed here, as influencing entrepreneurship is also likely to influence imitation in the same direction. This paper does not explore the implications of replictive entrepreneurship.

18 To improve tractability, we do not consider self-financing as a viable possibility. This connects with Schumpeter (1911 [1934]), who was adamant that the entrepreneur is not a riskbearer. Risk bearing is the function of the capitalist who lends his funds to the entrepreneur.
}

$\dot{V}(t) / V(t)+\pi / V(t)=r(t)+\kappa, \dot{V}(t)=0$

$\pi / V(t)=r(t)+\kappa \equiv \tilde{r}$

i.e., the higher risks associated with an investment in incumbents (because they may become replaced and a capital loss may be incurred) require a higher return in steady state.

To close the model intertemporal consumption must match intertemporal production-i.e., entry of new goods and start-ups reliant upon access to capital. Such an exercise implies solving a dynamic consumption (growth) model subject to a budget constraint (returns on savings and wages). This will not be undertaken here since our predominant interest is entry, not growth. However, in equilibrium the standard dynamic equilibrium condition will apply, implying that the consumer rate of time-preferences $(\rho)$ must equal the rate of return $(\tilde{r})$ of investments over time. Then capital flows to the financial market (savings that is invested in new ventures) correspond exactly to demand for new products of intertemporally utility-maximizing consumers. Note that this does not imply a continuous flow of innovation for each period of time.

Embarking from a traditional consumer utility function, where utility is increasing in new and high quality goods, it was shown how either incumbents or start-ups supply such goods. The production technology only requires labor. Incumbents will employ labor in $R \& D$, whereas new entrepreneurs will engage in production by drawing upon the existing stock of knowledge. Both types of firms depend on capital injections to finance innovation. This is supplied by the financial market through savings by households. Since firms may be threatened by innovation, investors require a riskadjusted rate of return to invest in either incumbents or start-ups. Equilibrium in the labor market is assured by the assumption of free mobility across sectors, while free entry in the long-run drives profits to zero.

\section{Empirical analysis}

According to this model, expected profits from entrepreneurship are enhanced by the magnitude of new knowledge, but constrained by the commercialization capabilities of incumbent firms. 


\subsection{The hypotheses}

Given that entrepreneurial activity exceeds zero, the following testable hypotheses are derived from our model (see Appendix A):

Hypothesis 1 An increase in the stock of knowledge is expected to positively impact the degree of entrepreneurship.

Hypothesis 2 The more efficient incumbents are at exploiting $\mathrm{R} \& \mathrm{D}$, the smaller the effect of a given knowledge stock on entrepreneurship. ${ }^{19}$

Hypothesis 3 Entrepreneurial activities can be expected to decrease under higher regulations, administrative barriers and governmental intervention in the market.

Our model explains entrepreneurship as a function of the following factors: knowledge stock (KSTOCK), R\&D exploitation by incumbents (INC) and barriers to entrepreneurship captured by $\sigma$ (BARR). It considers factors such as risk aversion, legal restrictions, bureaucratic constraints, labor market rigidities, taxes, lack of social acceptance, etc. (Parker 2004). The existence of such barriers is reflected by a low value of $\sigma$. This explains why economic agents might decide against starting up, even when in possession of knowledge that promises potential profit opportunity. In addition, culture, traditions and institutions are more difficult factors to identify than strictly economic factors, but they also play an important role in entrepreneurship. To capture such country-specific differences, we estimate a reduced form equation with a fixed-effect panel regression technique, ${ }^{20}$

$$
\begin{aligned}
\mathrm{ENT}_{j, t}= & \lambda_{j}+\alpha \mathrm{KSTOCK}_{j, t}+\mathrm{BARR}_{j, t}^{\prime} \beta+\mathrm{INC}_{j, t}^{\prime} \gamma \\
& +\alpha_{4} Z_{j, t}^{\prime} \delta+\varepsilon_{j, t}
\end{aligned}
$$

\footnotetext{
19 The efficiency with which incumbents exploit knowledge is, in part, related to the incentive structure and intellectual property rights of the firm (Moen 2005; Hellmann 2007; Hvide 2006).

${ }^{20}$ The choice of empirical model is based on an $F$-test to check the validity of using a fixed-effect regression technique as compared to OLS. The test clearly rejects the null hypotheses of all fixed effects jointly being zero. We also estimated the model without fixed effects, which yields unstable results. A dynamic panel estimation is also a possible approach, but is more appropriate for limited time series data with many panels. The current paper has rather long time series with few panels.
}

where $j$ denotes country, $t$ represents time and $\mathrm{Z}$ is a vector of control variables. The error term is expected to exhibit standard properties: That is, $\varepsilon_{j, t}$ is assumed to have an independent and identical distribution with a zero mean and variance $\sigma^{2}$ for all $j$ and $t$.

\subsection{The variables}

The dependent variable, entrepreneurship (ENT), proxies country share of self-employed as a percentage of the labor force. ${ }^{21}$ There are several reasons to expect the self-employment rate to decrease as economies become more developed. Blau (1987) argues this is a fundamental economic change. He shows that the time series of self-employment is correlated with a measure of the extent to which technological change has been biased towards industries in which self-employment is important. Acs et al. (1994a) document the diversity in self-employment across countries and in time-series by examining variations in self-employment rates across OECD countries. However, the convergence of several factors, notably the decline in heavy manufacturing, growth of services and possibly the bias towards technological change in the 1990s tended to stem the decline in self-employment for most OECD countries. The self-employment rate is the best available measure across-countries and over time, and it serves as an acceptable proxy for high-impact entrepreneurship. $^{22}$

With respect to explanatory variables, our main focus is the endowment of knowledge within an economy. We first elaborate a stock measure composed of accumulated annual R\&D flows, assuming an annual depreciation rate of ten percent (KSTOCK). For the time period we are investigating (1981-2002), this implies a rapid accumulation of knowledge stock in the first 10 years (up to 1991) followed by more stable development where change in the knowledge stock is determined by annual outlays on $R \& D$. Obviously, this can insert biases into the estimations. We have therefore chosen to approximate knowledge stocks over the entire period with annual R\&D flows,

\footnotetext{
$\overline{21}$ The agricultural sector has been excluded.

22 Start-up data are available from the World Bank, but for a different set of countries across a considerably shorter period (1997-2004). See Klapper et al. (2007) for more. The data are shown to be positively (but weakly) correlated with the selfemployment data used in the current study.
} 
which actually constitutes variation in the stock variable once the stock has been built up. Considering that the correlation between the knowledge stock variable and $R \& D$ flows was very strong, annual $R \& D$ outlays are an acceptable approximation for knowledge stocks. ${ }^{23}$ In line with our model, we expect an increase in relative knowledge endowment to increase the profitability of entrepreneurial activity by facilitating the recognition of entrepreneurial opportunities. The knowledge variable is normalized by GDP.

The most difficult variable to model empirically is incumbent intra-temporal exploitation of knowledge. We use two variables that are important indicators of the extent to which incumbents draw upon knowledge flows. The first is the number of patents (PATENTS) in relation to population, where a higher proportion implies that incumbents use more of the existing knowledge flows (Griliches 1986). ${ }^{24}$ The second approximation is the gap between actual and potential GDP (GAP). The argument is that full employment of the economy resources, a small percentage difference between actual and potential GDP, diminishes possibilities for start-ups through exploitation of knowledge flows. Both variables are assumed to influence entrepreneurship negatively.

We use two variables to capture the extent of barriers to entrepreneurship in an economy. First, we incorporate public expenditure in relation to GDP (GEXP) as an approximation of total tax pressure and the extent of regulatory interventions in the economy (Nicoletti et al. 2000). As an alternative, we also include tax share in GDP for both individual (TAXPERS) and corporate firms (TAXCORP). Start-ups are less likely to occur if incentive structures are distorted through high taxes (Henrekson 2005). We expect these variables to be negatively associated with entrepreneurship. ${ }^{25}$

\footnotetext{
${ }^{23}$ For the full sample the correlation coefficient between knowledge stocks and R\&D flows varied between 0.95 and 0.98 (5-year averages), depending on the lag-structure. There are some variations across countries. $R \& D$ data are not available prior to 1981; hence, it was not possible to construct knowledge stocks using data from the 1970s.

${ }^{24}$ Giuri et al. (2007) and Braunerhjelm and Svensson (2008) provide evidence that large companies hold the dominating part of patents.

25 We could also use the World Bank cost of doing business as an alternative measure barrier to entry.
}

In addition to the above variables, we also include a number of control variables where previous research indicates influence on entrepreneurship. Numerous studies claim urban environments are particularly conducive to entrepreneurial activities, innovation and growth because of agglomeration economies (Jacobs 1969; Krugman 1991). Information flows are denser in cities, where different competencies and financial resources are more accessible, and market proximity is obvious (Acs et al. 1994b). We therefore include a variable to capture the share of the population living in urban areas (URBAN). We expect greater urbanization to be reflected in higher entrepreneurial activities. Studies on demographic variables conclude that individuals in the age cohort 30-44 are most likely to undertake entrepreneurial activities. A large share of population in this cohort (AGE) is expected to relate positively to the share of entrepreneurs. In order to smooth out business fluctuations, we control for economic growth, defined as a 5-year moving average (GROWTH). Finally, we control for time-specific effects by implementing either period dummies, annual dummies or a time trend. ${ }^{26}$

All regressions are based on data for 19 OECD countries for the period 1981 to 2002. Data come predominantly from the OECD, but other sources are also used (see Appendix B). ${ }^{27}$ Summary statistics and correlations are listed in Tables 1 and 2, respectively.

\section{Regression results}

Regression results estimating the entrepreneurship rate (ENT) for 1981-2002 are presented in Tables 3 and 4. These results are consistent with the predictions of our model. Entrepreneurial opportunities do not appear to be exogenous but rather systematically created by a high presence of knowledge spillovers. As the positive and statistically significant coefficients of the knowledge stock suggest, entrepreneurial activity tends to be greater where knowledge is more prevalent.

\footnotetext{
${ }^{26}$ For instance, Jorgenson (2001) argues that increased technological change enhanced entrepreneurial activity, particularly in the 1990s.

27 The following countries are included: Australia, Austria, Belgium, Canada, Denmark, Finland, France, Germany, Ireland, Italy, Japan, The Netherlands, New Zealand, Norway, Portugal, Spain, Sweden, the UK and US. For some variables with missing values, we have used the closest year available.
} 
Table 1 Descriptive statistics

\begin{tabular}{lcrcrl}
\hline Variable & Minimum & Mean & Maximum & SD & Observations \\
\hline ENT & 2.83 & 4.90 & 8.41 & 1.37 & 418 \\
KSTOCK & .28 & 1.77 & 4.63 & .75 & 411 \\
GEXP & 30.2 & 47.87 & 72.93 & 8.43 & 412 \\
TAXPERS & 3.83 & 11.54 & 26.22 & 4.74 & 410 \\
TAXCORP & .27 & 2.87 & 8.92 & 1.31 & 410 \\
PATENT & $9.8 \mathrm{E}^{-4}$ & .28 & 1.38 & .26 & 414 \\
GAP & -10.90 & -.65 & 6.83 & 2.65 & 418 \\
GROWTH & -3.02 & 2.64 & 9.77 & 1.51 & 418 \\
URBAN & 43.3 & 74.13 & 97.10 & 11.66 & 418 \\
AGE & 16.87 & 21.88 & 25.60 & 1.72 & 418 \\
\hline
\end{tabular}

Table 3 reports results where no lags are implemented on the knowledge stock variable. In the first three regressions, variables are defined as 5-year averages, while the remaining three implement annual data. ${ }^{28}$ Different versions of the time variables are used in the estimations, albeit the results are quite robust regardless of variable specification. When data are defined as 5-year averages in the estimations, the knowledge stock is shown to be positive in all regressions and significant in two of three. With respect to the remaining variables, only demographic structure (AGE) has a consistent and significant impact on entrepreneurship. Incumbent exploitation of knowledge (PATENT and GAP) and barriers to entrepreneurship (GEXP and taxes) have the expected negative signs but are insignificant. Only personal income taxes have a weak negative and significant impact on entrepreneurship.

One reason for the relatively low explanatory value of these regressions may be the limited number of observations from using 5-year averages for the estimations. When the regressions are repeated using annual data, the significance of the knowledge stock variable is strengthened considerably. This is also the case for variables representing entrepreneurial barriers and the impact of incumbents. Note that the patent variable is significant in all regressions, suggesting that extensive knowledge exploitation by incumbents is negatively related to entrepreneurial activity. The lower the ability of incumbents to appropriate new knowledge, the more knowledge will spill over to third parties, as predicted by the theory. Hence, to the degree

\footnotetext{
28 Averages are calculated for the periods 1981-85, 1986-90, 1991-95 and 1996-2002. The average for the last period is based on 7 years.
}

that incumbent firms take advantage of opportunities, there will be less entrepreneurial activity. The GAP variable, admittedly defined at an aggregate level, fares less well. Public expenditure (GEXP), which indicates a wide set of barriers to entrepreneurship, has a negative and significant effect on entrepreneurship. As we substitute government expenditure for the two tax variables, the negative and statistically significant coefficient of the personal tax rate indicates that personal taxes are a barrier to entrepreneurship. The positive and weak significance of the corporate tax rate may actually indicate that a higher rate of corporate taxes reduces the propensity for incumbent firms to appropriate returns from opportunities. This can generate more entrepreneurial opportunities.

A lag structure ranging from 1 to 3 years is imposed on the knowledge stock variable, as shown in Table 4. One regression is shown with variables defined as 5year averages; remaining regressions use annual data. We only present results for estimations using annual dummies. $^{29}$ In general, the estimations conform with the results in Table 3, particularly for variables related to knowledge stock, barriers to entrepreneurship and incumbents exploitation of knowledge. The patent variable always presents a negative sign (as does the GAP variable with one exception), and is significant in four of the five regressions using annual data.

Table 2 reports a relatively high correlation coefficient (.74) between the knowledge stock variable (KSTOCK) and the patent variable (PATENT). A similar but weaker coefficient (.47) is

\footnotetext{
${ }^{29}$ Independent of the time variable used (trend, period dummy or year dummy), the results are quite robust. Regression results using alternative time specifications are available from the authors on request.
} 
Table 2 Correlation matrix, independent variables, 5-year averages, period dummies

\begin{tabular}{|c|c|c|c|c|c|c|c|c|c|c|}
\hline & KSTOCK & KSTOCK-1 & GEXP & TAX-PERS & TAX-CORP & PATENT & GAP & GROWTH & URBAN & AGE \\
\hline KSTOCK & 1 & & & & & & & & & \\
\hline KSTOCK-1 & .95 & 1 & & & & & & & & \\
\hline GEXP & .11 & .02 & 1 & & & & & & & \\
\hline TAXPERS & .15 & .02 & .45 & 1 & & & & & & \\
\hline TAXCORP & .09 & .10 & -.44 & -.17 & 1 & & & & & \\
\hline PATENT & .74 & .76 & .35 & .05 & -.19 & 1 & & & & \\
\hline GAP & -.04 & -.00 & -.26 & .00 & .20 & .02 & 1 & & & \\
\hline GROWTH & -.20 & -.22 & -.46 & -.16 & .29 & -.32 & .47 & 1 & & \\
\hline URBAN & .19 & .24 & .11 & .44 & -.00 & .08 & .02 & -.18 & 1 & \\
\hline AGE & .09 & .11 & -.06 & .14 & .01 & .04 & -.01 & -.16 & .19 & 1 \\
\hline
\end{tabular}

Note: Period dummies not shown. The correlation matrix for annual data is highly similar and is not shown, but of course available on request

Table 3 Regression results, country fixed-effect panels, 5-year averages and annual data

\begin{tabular}{|c|c|c|c|c|c|c|}
\hline \multirow{2}{*}{$\frac{\text { Dep. var: ENT }}{\text { KSTOCK }}$} & \multicolumn{3}{|c|}{ 5-year averages, trend or period dummies } & \multicolumn{3}{|c|}{ Annual data, trend or year dummies } \\
\hline & $\begin{array}{l}.54 * * \\
(2.09)\end{array}$ & $\begin{array}{l}.51^{*} \\
(1.97)\end{array}$ & $\begin{array}{l}.19 \\
(.67)\end{array}$ & $\begin{array}{l}.35 * * * \\
(4.02)\end{array}$ & $\begin{array}{l}.44 * * * \\
(4.93)\end{array}$ & $\begin{array}{l}.19 * * \\
(1.95)\end{array}$ \\
\hline GEXP & $\begin{array}{l}-.03 \\
(-1.60)\end{array}$ & $\begin{array}{l}-.03 \\
(-1.58)\end{array}$ & - & $\begin{array}{l}-.02 * * * \\
(-2.59)\end{array}$ & $\begin{array}{l}-.02 * * * \\
(-3.62)\end{array}$ & - \\
\hline TAXPERS & - & - & $\begin{array}{l}-.11 * \\
(-1.98)\end{array}$ & - & & $\begin{array}{l}-.08 * * * \\
(-4.67)\end{array}$ \\
\hline TAXCORP & - & - & $\begin{array}{l}.04 \\
(.53)\end{array}$ & - & & $\begin{array}{l}.05^{*} \\
(1.81)\end{array}$ \\
\hline PATENT & $\begin{array}{l}-.89 \\
(-1.27)\end{array}$ & $\begin{array}{l}-.56 \\
(-.91)\end{array}$ & $\begin{array}{l}-.50 \\
(-.82)\end{array}$ & $\begin{array}{l}-.30 * \\
(-1.68)\end{array}$ & $\begin{array}{l}-.74 * * * \\
(-3.39)\end{array}$ & $\begin{array}{l}-.66 * * * \\
(-3.04)\end{array}$ \\
\hline GAP & $\begin{array}{l}.01 \\
(.14)\end{array}$ & $\begin{array}{l}-.01 \\
(-.25)\end{array}$ & $\begin{array}{l}.00 \\
(.01)\end{array}$ & $\begin{array}{l}-.01 \\
(-.71)\end{array}$ & $\begin{array}{l}.01 \\
(.75)\end{array}$ & $\begin{array}{l}-.01 \\
(-.59)\end{array}$ \\
\hline GROWTH $^{\mathrm{a}}$ & $\begin{array}{l}-.04 \\
(-.45)\end{array}$ & $\begin{array}{l}-.04 \\
(-.66)\end{array}$ & $\begin{array}{l}.04 \\
(.58)\end{array}$ & $\begin{array}{l}.03 \\
(1.54)\end{array}$ & $\begin{array}{l}-.02 \\
(.87)\end{array}$ & $\begin{array}{l}.06 * * * \\
(2.79)\end{array}$ \\
\hline URBAN & $\begin{array}{l}.07 \\
(1.46)\end{array}$ & $\begin{array}{l}.07 \\
(1.56)\end{array}$ & $\begin{array}{l}.01 \\
(.20)\end{array}$ & $\begin{array}{l}.09 * * * \\
(5.21)\end{array}$ & $\begin{array}{l}.08 * * * \\
(4.70)\end{array}$ & $\begin{array}{l}.03 \\
(1.49)\end{array}$ \\
\hline AGE & $\begin{array}{l}.21 * * * \\
(3.55)\end{array}$ & $\begin{array}{l}.23 * * * \\
(4.37)\end{array}$ & $\begin{array}{l}.22 * * * \\
(4.19)\end{array}$ & $\begin{array}{l}.23 * * * \\
(12.79)\end{array}$ & $\begin{array}{l}.21 * * * \\
(10.29)\end{array}$ & $\begin{array}{l}.19 * * * \\
(10.12)\end{array}$ \\
\hline TREND $^{\mathrm{b}}$ & - & $\begin{array}{l}.01 \\
(.09)\end{array}$ & $\begin{array}{l}.10 \\
(.86)\end{array}$ & $\begin{array}{l}-.00 \\
(-.33)\end{array}$ & - & - \\
\hline YEAR/PERIOD DUMMIES & YES & NO & NO & NO & YES & YES \\
\hline CONSTANT & $\begin{array}{l}-3.99 \\
(-.92)\end{array}$ & $\begin{array}{l}-4.94 \\
(-1.19)\end{array}$ & $\begin{array}{l}-.08 \\
(-.02)\end{array}$ & $\begin{array}{l}-6.69 * * * \\
(-4.57)\end{array}$ & $\begin{array}{l}-6.16^{* * *} \\
(-3.51)\end{array}$ & $\begin{array}{l}-1.19 \\
(-.76)\end{array}$ \\
\hline$R^{2}$ & .64 & .63 & .64 & .60 & .63 & .61 \\
\hline$F$ & 8.04 & 9.88 & 8.64 & 71.87 & 22.13 & 19.15 \\
\hline No. of obs. & 73 & 73 & 72 & 408 & 408 & 403 \\
\hline
\end{tabular}

${ }^{\text {a }}$ Growth is defined as a 5-year moving average when annual data are implemented

b Linear time trend 
Table 4 Regression results, country fixed-effect panels, 5-year averages (first column) and annual data, lagged knowledge stock variable

\begin{tabular}{|c|c|c|c|c|c|c|}
\hline Dep. var: ENT & 5-year average & Annual data & & & & \\
\hline KSTOCK-1 & $\begin{array}{l}.85^{*} \\
(1.70)\end{array}$ & $\begin{array}{l}.23 * * \\
(2.26)\end{array}$ & - & - & - & - \\
\hline KSTOCK-2 & - & - & $\begin{array}{l}.47 * * * \\
(4.52)\end{array}$ & $\begin{array}{l}.26 * * \\
(2.38)\end{array}$ & - & - \\
\hline KSTOCK-3 & - & - & & - & $\begin{array}{l}.46 * * * \\
(3.95)\end{array}$ & $\begin{array}{l}.27 * * \\
(2.28)\end{array}$ \\
\hline GEXP & $\begin{array}{l}-.06^{*} \\
(-1.77)\end{array}$ & - & $\begin{array}{l}-.03 * * * \\
(-3.44)\end{array}$ & - & $\begin{array}{l}-.03 * * * \\
(-3.49)\end{array}$ & - \\
\hline TAXPERS & - & $\begin{array}{l}-.09 * * * \\
(-5.10)\end{array}$ & - & $\begin{array}{l}-.09 * * * \\
(-5.26)\end{array}$ & - & $\begin{array}{l}-.09 * * * \\
(-5.34)\end{array}$ \\
\hline TAXCORP & - & $\begin{array}{l}.04 \\
(1.44)\end{array}$ & - & $\begin{array}{l}.02 \\
(1.01)\end{array}$ & - & $\begin{array}{l}.02 \\
(.87)\end{array}$ \\
\hline PATENT & $\begin{array}{l}-.26 \\
(-.25)\end{array}$ & $\begin{array}{l}-.59 * * * \\
(-2.63)\end{array}$ & $\begin{array}{l}-.57 * * * \\
(-2.32)\end{array}$ & $\begin{array}{l}-.50^{* *} \\
(-2.09)\end{array}$ & $\begin{array}{l}-.45^{*} \\
(-1.74)\end{array}$ & $\begin{array}{l}-.40 \\
(-1.62)\end{array}$ \\
\hline GAP & $\begin{array}{l}-.06 \\
(-1.56)\end{array}$ & $\begin{array}{l}-.01 \\
(-.61)\end{array}$ & $\begin{array}{l}.00 \\
(.10)\end{array}$ & $\begin{array}{l}-.01 \\
(-.92)\end{array}$ & $\begin{array}{l}-.00 \\
(-.28)\end{array}$ & $\begin{array}{l}-.02 \\
(-1.18)\end{array}$ \\
\hline GROWTH $^{\mathrm{a}}$ & $\begin{array}{l}-.05 \\
(-.60)\end{array}$ & $\begin{array}{l}.06 * * * \\
(2.82)\end{array}$ & $\begin{array}{l}.03 \\
(1.07)\end{array}$ & $\begin{array}{l}.05 * * * \\
(3.00)\end{array}$ & $\begin{array}{l}.03 \\
(1.07)\end{array}$ & $\begin{array}{l}.06 * * * \\
(2.97)\end{array}$ \\
\hline URBAN & $\begin{array}{l}.13 * * \\
(2.18)\end{array}$ & $\begin{array}{l}.03 * \\
(1.80)\end{array}$ & $\begin{array}{l}.10^{* * * *} \\
(5.52)\end{array}$ & $\begin{array}{l}.04 * * \\
(2.20)\end{array}$ & $\begin{array}{l}.10^{* * * *} \\
(5.44)\end{array}$ & $\begin{array}{l}.05 * * * \\
(2.48)\end{array}$ \\
\hline AGE & $\begin{array}{l}.23 * * * \\
(3.22)\end{array}$ & $\begin{array}{l}.21 * * * \\
(10.30)\end{array}$ & $\begin{array}{l}.22 * * * \\
(10.19)\end{array}$ & $\begin{array}{l}.21 * * * \\
(10.40)\end{array}$ & $\begin{array}{l}.21^{* * *} \\
(9.83)\end{array}$ & $\begin{array}{l}.21 * * * \\
(10.32)\end{array}$ \\
\hline TREND $^{\mathrm{b}}$ & $\begin{array}{l}-.17 \\
(-1.01)\end{array}$ & - & - & - & - & - \\
\hline YEAR/PERIOD DUMMIES & NO & YES & YES & YES & YES & YES \\
\hline CONSTANT & $\begin{array}{l}7.66 \\
(-1.39)\end{array}$ & $\begin{array}{l}-1.71 \\
(-1.07)\end{array}$ & $\begin{array}{l}-6.47 * * * \\
(-4.19)\end{array}$ & $\begin{array}{l}-2.30 \\
(-1.42)\end{array}$ & $\begin{array}{l}-6.50 * * * \\
(-4.01)\end{array}$ & $\begin{array}{l}-2.72 * \\
(-1.66)\end{array}$ \\
\hline$R^{2}$ & .60 & .61 & .62 & .60 & .60 & .59 \\
\hline$F$ & 5.28 & 18.88 & 20.82 & 17.80 & 18.74 & 16.44 \\
\hline No. of obs. & 55 & 385 & 372 & 367 & 353 & 349 \\
\hline
\end{tabular}

${ }^{a}$ Growth is defined as a 5-year moving average when annual data are implemented

b Linear time trend

obtained for the variables GROWTH and GAP, i.e., the difference between potential and actual GDP. Finally, the variables GROWTH and governmental expenditure (GEXP) display a similar degree of correlation (.46). This may introduce multicollinearity into the regressions, making the estimators less efficient, albeit still unbiased. We therefore rerun the regressions where we have excluded GAP (all regressions) and control for the impact of the exclusion in the regressions of either PATENT or GEXP on the other estimates.
As shown in Tables 5 and 6, removing the patent variable from the regressions does not influence the estimates of the knowledge stock variable. However, when we omit GEXP the control variable GROWTH turns significantly positive, but the remaining variables are basically unaffected (if the growth variable is omitted, the significance of the GEXP variable is strengthened). Hence, these correlations have only a minor influence on the results.

Thus, the empirical findings that entrepreneurship tends to be systematically greater in the presence of 
Table 5 Regression results, country fixed-effect panels, 5-year averages and annual data

\begin{tabular}{|c|c|c|c|c|c|c|}
\hline \multirow{2}{*}{$\frac{\text { Dep. var: ENT }}{\text { KSTOCK }}$} & \multicolumn{3}{|c|}{ 5-year averages, trend } & \multicolumn{3}{|c|}{ Annual data, trend } \\
\hline & $\begin{array}{l}.42 * \\
(1.71)\end{array}$ & $\begin{array}{l}.51 * * \\
(1.96)\end{array}$ & $\begin{array}{l}.51 * * \\
(2.03)\end{array}$ & $\begin{array}{l}.31 * * * \\
(3.63)\end{array}$ & $\begin{array}{l}.35 * * * \\
(4.12)\end{array}$ & $\begin{array}{l}.36^{* * * *} \\
(4.13)\end{array}$ \\
\hline GEXP & - & $\begin{array}{l}-.02 \\
(-1.11)\end{array}$ & $\begin{array}{l}-.03 \\
(-1.60)\end{array}$ & - & $\begin{array}{l}-.02 * * * \\
(-2.62)\end{array}$ & $\begin{array}{l}-.02 * * * \\
(-2.57)\end{array}$ \\
\hline PATENT & - & - & $\begin{array}{l}-.58 \\
(-.96)\end{array}$ & - & - & $\begin{array}{l}-.30 * \\
(-1.67)\end{array}$ \\
\hline GROWTH $^{\mathrm{a}}$ & $\begin{array}{l}.03 \\
(.75)\end{array}$ & $\begin{array}{l}-.01 \\
(-.11)\end{array}$ & $\begin{array}{l}-.05 \\
(-.77)\end{array}$ & $\begin{array}{l}.06 * * * \\
(4.10)\end{array}$ & $\begin{array}{l}.03 \\
(1.60)\end{array}$ & $\begin{array}{l}.02 \\
(1.43)\end{array}$ \\
\hline URBAN & $\begin{array}{l}.11 * * * \\
(2.54)\end{array}$ & $\begin{array}{l}.11 * * * \\
(2.60)\end{array}$ & $\begin{array}{l}.07 \\
(1.56)\end{array}$ & $\begin{array}{l}.09 * * * \\
(5.89)\end{array}$ & $\begin{array}{l}.10 * * * \\
(6.09)\end{array}$ & $\begin{array}{l}.09 * * * \\
(5.17)\end{array}$ \\
\hline AGE & $\begin{array}{l}.26 * * * \\
(45.55)\end{array}$ & $\begin{array}{l}.25 * * * \\
(3.55)\end{array}$ & $\begin{array}{l}.23 * * * \\
(4.41)\end{array}$ & $\begin{array}{l}.25 * * * \\
(14.07)\end{array}$ & $\begin{array}{l}.25 * * * \\
(14.26)\end{array}$ & $\begin{array}{l}.23 * * * \\
(12.78)\end{array}$ \\
\hline TREND $^{\mathrm{b}}$ & $\begin{array}{l}-.08 \\
(-.88)\end{array}$ & $\begin{array}{l}-.09 \\
(.1 .05)\end{array}$ & $\begin{array}{l}.01 \\
(.10)\end{array}$ & $\begin{array}{l}-.01 \\
(-1.42)\end{array}$ & $\begin{array}{l}-.01 * \\
(-1.83)\end{array}$ & $\begin{array}{l}-.01 \\
(-.34)\end{array}$ \\
\hline CONSTANT & $\begin{array}{l}-9.38^{* * *} \\
(-2.72)\end{array}$ & $\begin{array}{l}-8.74 * * * \\
(-2.50)\end{array}$ & $\begin{array}{l}-4.81 \\
(-1.18)\end{array}$ & $\begin{array}{l}-8.08 * * * \\
(-6.04)\end{array}$ & $\begin{array}{l}-7.57 * * * \\
(-5.63)\end{array}$ & $\begin{array}{l}-6.50 \\
(-4.52)\end{array}$ \\
\hline$R^{2}$ & .64 & .65 & .63 & .60 & .61 & .60 \\
\hline$F$ & 17.88 & 15.17 & 11.52 & 117.53 & 100.57 & 182.17 \\
\hline No. of obs. & 74 & 74 & 73 & 411 & 411 & 408 \\
\hline
\end{tabular}

${ }^{a}$ Growth is defined as a 5-year moving average when annual data are implemented

b Linear time trend

Table 6 Regression results, country fixed-effect panels, annual data, lagged knowledge stock variable

\begin{tabular}{|c|c|c|c|c|c|c|}
\hline \multicolumn{7}{|c|}{ Dep. var: ENT } \\
\hline \multirow[t]{2}{*}{ KSTOCK-1 } & $.46^{* * *}$ & $.41 * * *$ & - & - & - & - \\
\hline & $(3.87)$ & (4.39) & & & & \\
\hline \multirow[t]{2}{*}{ KSTOCK-2 } & - & - & $.39 * * *$ & $.45 * * *$ & - & - \\
\hline & & & $(3.96)$ & $(4.44)$ & & \\
\hline \multirow[t]{2}{*}{ KSTOCK-3 } & - & - & - & - & $.43 * * *$ & $.48 * * *$ \\
\hline & & & & & (3.99) & $(4.32)$ \\
\hline \multirow[t]{2}{*}{ GEXP } & - & $-.02 * * *$ & - & $-.02 * * *$ & - & $-.02 * * *$ \\
\hline & & $(-2.64)$ & & $(-2.65)$ & & $(-2.63)$ \\
\hline \multirow[t]{2}{*}{ PATENT } & - & -.22 & - & -.12 & - & -.02 \\
\hline & & $(-1.17)$ & & $(-.58)$ & & $(-.07)$ \\
\hline \multirow[t]{2}{*}{ GROWTH $^{\mathrm{a}}$} & $.06 * * *$ & .02 & $.05 * * *$ & .02 & $.05 * * *$ & .02 \\
\hline & $(3.88)$ & $(1.20)$ & $(3.73)$ & (1.05) & (3.57) & $(.88)$ \\
\hline \multirow[t]{2}{*}{ URBAN } & $.10 * * *$ & $.09 * * *$ & $.11 * * *$ & $.10 * * *$ & $.11 * * *$ & $.11 * * *$ \\
\hline & $(6.23)$ & $(5.69)$ & $(6.48)$ & (6.19) & $(6.52)$ & (6.18) \\
\hline \multirow[t]{2}{*}{ AGE } & $.25 * * *$ & $.24 * * *$ & $.25 * * *$ & $.24 * * *$ & $.25^{* * *}$ & $.24 * * *$ \\
\hline & (13.98) & (12.91) & (13.71) & (12.91) & (13.32) & (12.67) \\
\hline \multirow[t]{2}{*}{ TREND $^{\mathrm{b}}$} & $-.01 *$ & -.01 & $-.01 *$ & -.01 & $-.01 *$ & $-.01 *$ \\
\hline & $(-1.71)$ & $(-.97)$ & $(-1.86)$ & $(-1.54)$ & $(1.86)$ & $(-1.86)$ \\
\hline
\end{tabular}


Table 6 continued

\begin{tabular}{lllllll}
\hline Dep. var: ENT & \multicolumn{7}{l}{} \\
\hline CONSTANT & $-8.79 * * *$ & $-7.32 * * *$ & $-9.30^{* * *}$ & $-8.07 * * *$ & $-9.58^{* * *}$ & $-8.25 * * *$ \\
& $(-6.40)$ & $(-5.07)$ & $(-6-62)$ & $(-5.58)$ & $(-6.66)$ & $(-5.54)$ \\
$R^{2}$ & .60 & .61 & .60 & .60 & .58 & .58 \\
$F$ & 11.73 & 78.80 & 102.43 & 73.52 & 91.17 & 64.60 \\
No. of obs. & 392 & 390 & 373 & 372 & 354 & 353 \\
\hline
\end{tabular}

${ }^{a}$ Growth is defined as a 5-year moving average when annual data are implemented

b Linear time trend

knowledge spillovers are strikingly robust. Although the significance and even sign of some control variables are more sensitive to time period and variable specification, entrepreneurial activity responds positively to economic knowledge, regardless of time and variable specification.

\section{Conclusions}

This paper has developed a Knowledge Spillover Theory of Entrepreneurship in which the creation of new knowledge expands the set of technological opportunity. Therefore, entrepreneurial activity does not involve simply the arbitrage of opportunities, but also the exploitation of intra-temporal knowledge spillovers not appropriated by incumbent firms. The theory focuses on individual agents with endowments of new economic knowledge as the unit of analysis in a model of economic growth, rather than exogenously assumed firms. Agents with new knowledge endogenously pursue the exploitation of knowledge. This suggests that knowledge spillovers come from the stock of knowledge, and there is a strong relationship between such spillovers and entrepreneurial activity. If incumbent firms appropriated all the rents of $R \& D$, there would be no intra-temporal knowledge spillovers.

There are several implications of these findings for future research. First, theories of entrepreneurship need to explain where opportunities come from, how intra-temporal knowledge spillovers occur, and the dynamics of occupational choice leading to new firm formation. Prevailing theories of entrepreneurship do not address these questions. Second, the theory helps better understand the contradictions in Smith's Wealth of Nations between increasing returns (the pin factory) and how the market economy can harness self-interest to the common good, leading individuals to unintentional ends (the invisible hand). The real challenge in endogenous growth theory is not that the firm will under-invest in new knowledge, but how to balance increasing returns with competition. The theory provides an explanation of the role of the individual and the firm in the economy. If Romer inspired a new economics of knowledge, The Knowledge Spillover Theory of Entrepreneurship brings us a step closer to understanding the essential role of the entrepreneur in the market economy. Finally, the role of intellectual property rights protection needs to be revaluated in light of the theory. If intellectual property protection becomes too strong, and all rents accrue to the producer of knowledge, it will reduce intra-temporal knowledge spillovers, and ultimately innovation and growth (Acs and Sanders 2008).

Acknowledgements We thank discussants at the 2007 DRUID conference in Copenhagen, Sameeksha Desai, Larry Plummer, Mark Sanders, Scott Shane, Mariagrazia Squicciarini, Siri Terjesen and two anonymous referees for valuable comments. We would also like to thank Per Thulin and Benny Borgman for excellent research assistance and the Marianne and Marcus Wallenberg Foundation for generous financial support.

Open Access This article is distributed under the terms of the Creative Commons Attribution Noncommercial License which permits any noncommercial use, distribution, and reproduction in any medium, provided the original author(s) and source are credited.

\section{Appendix A}

From Eqs. 5, 6 and 7, the impact of a change in the knowledge stock $(\mathrm{K}), \mathrm{R} \& \mathrm{D}$ efforts by incumbents $\left(L_{R}\right)$ and in the efficiency parameter $(\sigma, 0<\sigma<1)$, where values close to zero in the efficiency variable implies fewer obstacles in introducing new products, can be derived as 
Table 7 Definition of variables and data source

\begin{tabular}{|c|c|c|}
\hline Variable & Definition & Sources \\
\hline ENT & $\begin{array}{l}\text { Dependent variable. Non-agricultural self-employed, as percentage of } \\
\text { total non-agricultural employment }\end{array}$ & EIM, The COMPENDIA Database \\
\hline KSTOCK & $\begin{array}{l}\text { Gross domestic expenditure on R\&D as percentage of GDP. KSTOCK-t } \\
\text { refers to different lag structures }\end{array}$ & $\begin{array}{l}\text { OECD, Main Science and } \\
\text { Technology Indicators }\end{array}$ \\
\hline GEXP & Total government disbursements as percentage of GDP & OECD, Economic Outlook \\
\hline TAXPERS & Taxes on personal income, as percentage of GDP & OECD, Revenue Statistics \\
\hline TAXCORP & Taxes on corporate income, as percentage of GDP & OECD, Revenue Statistics \\
\hline PATENT & $\begin{array}{l}\text { Number of patents applications to the EPO by residence of the inventor } \\
\text { (date of grant) divided by total population expressed in } 10,000\end{array}$ & OECD, Patent Database \\
\hline GAP & $\begin{array}{l}\text { Difference between actual annual GDP and potential GDP, divided by } \\
\text { potential GDP }\end{array}$ & OECD, Economic Outlook \\
\hline GROWTH & $\begin{array}{l}\text { Average growth over } 5 \text { years. Alternatively (see notes in the regression } \\
\text { tables), 5-year moving average of gross domestic product growth (at } \\
\text { the price levels and PPPs of 1995) }\end{array}$ & $\begin{array}{l}\text { OECD, National Accounts vol. 1, } \\
\text { Main Aggregates; OECD, } \\
\text { Economic Outlook } \\
\text { for Germany }\end{array}$ \\
\hline URBAN & The share of the total population living in urban areas & $\begin{array}{l}\text { World Bank, World Development } \\
\text { Indicators }\end{array}$ \\
\hline AGE & $\begin{array}{l}\text { Share of population between } 30 \text { and } 44 \text { years of age. Data published } \\
\text { every 5th year. Intermediate values estimated by cubic splines }\end{array}$ & $\begin{array}{l}\text { United Nations; OECD, Economic } \\
\text { Outlook }\end{array}$ \\
\hline TREND & Linear time trend & \\
\hline
\end{tabular}

$\kappa_{K}=(1 / \sigma) \gamma \mathrm{K}^{\gamma-1}>0$,

$$
\kappa_{K K}=(1 / \sigma)(\gamma-1) \gamma \mathrm{K}^{\gamma-2}<0 \quad(\gamma<1), \quad(\text { A.1a })
$$$$
\kappa_{L_{R}}=(1 / \sigma) \gamma L_{R}^{\gamma-1}>0 \text {, }
$$$$
\kappa_{L_{R} L_{R}}=-(1 / \sigma)(\gamma-1) \gamma L_{R}^{\gamma-2}<0 \quad(\gamma<1)
$$

$\kappa_{\sigma}=-\left[\left(\mathrm{K}^{\gamma}\right)+(L)^{\gamma}\right] / \sigma^{2}<0$,

$$
\kappa_{\sigma \sigma}=2\left[\left(\mathrm{~K}^{\gamma}\right)+(L)^{\gamma}\right] / \sigma^{3}>0,
$$

implying that the probability of entrepreneurial startups is increasing in the knowledge stock (weighted by average entrepreneurial ability), but at a decreasing rate (A.1a). By increasing R\&D staff, incumbent firms increase the probability of launching a new quality, albeit at a decreasing rate (A.1b). Both types of innovation are positively affected by a more efficient economy, but at a decreasing rate (A.1c).

\section{Appendix B}

See Table 7.

\section{References}

Acs, Z. J., \& Sanders, M. (2008). Intellectual property rights and the knowledge spillover theory of entrepreneurship. Working paper. Jena: Max Planck Institute of Economics.

Acs, Z. J., Audretsch, D. B., Braunerhjelm, P., \& Carlsson, B. (2004). The missing link: The knowledge filter and entrepreneurship in endogenous growth. Discussion Paper no. 4783. London, UK: Center for Economic Policy Research.

Acs, Z. J., Audretsch, D. B., \& Evans, D. S. (1994a). The determinants of variations in self-employment rates across countries and over time. Discussion Paper no. 871. London, UK: Centre for Economic and Policy Research.

Acs, Z. J., Audretsch, D. B., \& Feldman, M. P. (1994b). R\&D spillovers and recipient firm size. The Review of Economics and Statistics, 76, 336-340.

Acs, Z. J., \& Audretsch, D. B. (1988). Innovation in large and small firms: An empirical analysis. The American Economic Review, 78, 678-690.

Aghion, P., \& Howitt, P. (1992). A model of growth through creative destruction. Econometrica, 60, 323-351.

Anton, J. J., \& Yao, D. A. (1994). Expropriation and inventions: Appropriable rents in the absence of property rights. The American Economic Review, 84, 190-209.

Arrow, K. (1962). Economic welfare and the allocation of resources for invention. In R. Nelson (Ed.), The rate and direction of inventive activity. NJ: Princeton University Press and NBER. 
Audretsch, D. B. (1995). Innovation and industry evolution. Cambridge, USA: MIT Press.

Baumol, W. J. (2004). Entrepreneurial enterprises, large established firms and other components of the free-market growth machine. Small Business Economics, 23, 9-21.

Bhide, A. (1994). How entrepreneurs craft strategies that work. Harvard Business Review, 72, 150-161.

Blau, D. M. (1987). A time-series analysis of self-employment in the United States. The Journal of Political Economy, 95, 445-467.

Braunerhjelm, P., \& Svensson, R. (2008). The inventor's role: Was Schumpeter right? Journal of Evolutionary Economics, forthcoming.

Carlsson, B., \& Fridh, A.-C. (2002). Technology transfer in United States universities: A survey and statistical analysis. Journal of Evolutionary Economics, 12, 199232.

Dinopoulos, E. (1996). Schumpeterian growth theory: An overview. In E. Helmstädter \& M. Perlman (Eds.), Behavioral norms, technological progress and economic dynamics. Ann Arbor: The University of Michigan Press.

Gancia, G., \& Zilibotti, F. (2005). Horizontal innovation in the theory of growth and development. In P. Aghion \& S. Durlauf (Eds.), Handbook of economic growth. North Holland, Amsterdam: New York Elsevier.

Giuri, P., Mariani, M., Brusoni, S., Crespi, G., Francoz, D., Gambardella, A., et al. (2007). Inventors and invention processes in Europe: Results from the PatVal-EU survey. Research Policy, 36, 1107-1127.

Griliches, Z. (1979). Issues in assessing the contribution of $\mathrm{R} \& \mathrm{D}$ to productivity growth. Bell Journal of Economics, 10, 92-116.

Griliches, Z. (1986). Productivity, R\&D, and basic research at the firm level in the 1970s. The American Economic Review, 76, 141-154.

Hébert, R. F., \& Albert, N. (1982). The entrepreneur: Mainstream views and radical critiques. New York: Praeger.

Hellmann, T. (2007). When do employees become entrepreneurs? Management Science, 53, 919-933.

Henrekson, M. (2005). Entrepreneurship: A weak link in the welfare state? Industrial and Corporate Change, 14, 437467.

Howitt, P. (1999). Steady endogenous growth with population and R\&D inputs growing. Journal of Political Economy, 107, 715 .

Hvide, H. K. (2006). Firm size and the quality of entrepreneurs. Economic Journal, in press.

Intriligator, M. D. (1971). Mathematical optimization and economic theory. NJ: Prentice-Hall Englewood Cliffs.

Jacobs, J. (1969). The economy of cities. NY, USA: Random House.

Jaffe, A. B., Trajtenberg, M., \& Henderson, R. (1993). Geographic localization of knowledge spillovers as evidenced by patent citations. Quarterly Journal of Economics, 108, 577-598.

Jones, C. I. (1995). R\&D-based models of economic growth. Journal of Political Economy, 103, 759-784.
Jorgenson, D. W. (2001). Information technology and the US economy. The American Economic Review, 91, 1-32.

Kirzner, I. M. (1973). Entrepreneurship and competition. Chicago: University of Chicago Press.

Klapper, L., Amit, R., Guillén, M. F., \& Quesada, J. M. (2007). Entrepreneurship and firm formation across countries. Development Research Group Working Paper. Washington DC: World Bank.

Krugman, P. (1991). Increasing returns and economic geography. The Journal of Political Economy, 99, 483-499.

Lazear, E. P. (2005). Entrepreneurship. Journal of Labor Economics, 23, 649-680.

Lucas, R. E. J. R. (1978). On the size distribution of business firms. The Bell Journal of Economics, 9, 508-523.

Michelacci, C. (2003). Low returns in R\&D due to the lack of entrepreneurial skills. The Economic Journal, 113, 207225.

Moen, J. (2005). Is mobility of technical personnel a source of R\&D spillovers? Journal of Labor Economics, 23, 81-114.

Nicoletti, G., Scarpetta, S., \& Boylaud, O. (2000). Summary indicators of product market regulation with an extension to employment protection legislation. Concepts and measurement of labour markets flexibility/adaptability indicators. Paris: OECD Economics Department.

Pakes, A., \& Nitzan, S. (1983). Optimum contracts for research personnel, research employment, and the establishment of "Rival" Enterprises. Journal of Labor Economics, 1, 345365.

Parker, S. C. (2004). The economics of self-employment and entrepreneurship. New York: Cambridge University Press.

Romer, P. M. (1990). Endogenous technological change. The Journal of Political Economy, 98, 71-102.

Romer, P. M. (1996). Why, indeed, in America? Theory, history, and the origins of modern economic growth. The American Economic Review, 86, 202-206.

Scherer, F. M. (1965). Firm size, market structure, opportunity, and the output of patented inventions. The American Economic Review, 55, 1097-1125.

Schumpeter, J. (1911 [1934]). The theory of economic development, New York: Oxford University Press.

Segerstrom, P. S., Anant, T. C. A., \& Dinopoulos, E. (1990). A Schumpeterian model of the product life cycle. The American Economic Review, 80, 1077-1091.

Shackle, G. L. S. (1982). Foreword. In R. F. Hebert \& A. Link (Eds.), The entrepreneur: Mainstream views and radical critiques. New York: Praeger Publishers.

Shane, S. (2001). Technological opportunities and new firm creation. Management Science, 47, 205-220.

Thompson, P., \& Fox-Kean, M. (2005). Patent citations and the geography of knowledge spillovers: A reassessment. American Economic Review, 95, 450-460.

von Hayek, F. A. (1937). Economics and knowledge. Economica, 4, 33-54.

Zucker, L. G., Darby, M. R., \& Brewer, M. B. (1998). Intellectual human capital and the birth of us biotechnology enterprises. The American Economic Review, 88, 290306. 